\title{
Complex sporoderm structure in bryophyte spores: a palynological study of Erpodiaceae Broth.
}

\author{
Andrea Pereira Luizi-Ponzo ${ }^{1 *}$ (1) and Juliana da Costa Silva-e-Costa ${ }^{1}$ (i)
}

Received: October 26, 2018

Accepted: January 7, 2019

\begin{abstract}
Palynological studies of bryophytes are critical for evaluating the taxonomic relevance of their spores. They also provide important support to paleoecological investigations that, usually, treat bryophytes as a whole, which does not permit the evaluation of specific functional traits of a special taxonomic unit. The present study investigated the morphology and ultrastructure of spores of five species of Erpodiaceae (Bryophyta), and assessed the implications for taxonomy and the recognition of spores of past records. Erpodiaceae includes corticolous and saxicolous plants that are widely distributed throughout tropical and temperate regions. The spores were found to be isomorphic and apolar with a subcircular amb, granulate, inaperturate. The sporoderm possesses a perine, an exine and a stratified intine. The perine is largely responsible for spore surface ornamentation. The occurrence of exine projections, in isolation or sustaining the elements of the perine, characterizes sporoderm structure with features similar to that of a semitectum, a distinctive characteristic that has not been reported previously for bryophyte spores.
\end{abstract}

Keywords: bryophytes, mosses, palynology, spore, sporoderm, ultrastructure

\section{Introduction}

The moss family Erpodiaceae Broth. is widely distributed in tropical and temperate regions. The plants are small, prostrate, grow as mats and are autoicous and cladocarpous. Their stems are creeping and irregularly pinnate, while the leaves are oblong to oblong-ovate. They lack costa, have smooth or pluripapillose laminal cells, usually short seta and a capsule that is immersed to exserted (Pursell 1994; Pursell \& Allen 2002; Faria et al. 2018).

According to the classifications proposed by Frey \& Stech (2009) and Goffinet et al. (2009), Erpodiaceae includes five genera: Aulacopilum, Erpodium, Solmsiella, Venturiella, and Wildia.
Costa et al. (2011) and Yano (2011) report seven species of Erpodiaceae for Brazil, whereas Faria et al. (2018) consider there to be five.

The species occur on tree bark and branches (Vital 1980; Pursell \& Allen 2002) in forests and savannas, including the Cerrado and Caatinga, but particularly in areas having anthropic influences (Vital 1980; Faria et al. 2018).

Vital (1980) points out that species of Erpodiaceae occur in areas where vegetation is sparse, even when in forests, where they receive high luminosity. Their forophytes typically have a corky bark.

Little is known about the spores of species of Erpodiaceae. Erdtman (1965) described spores of Erpodium beccarii (as Erpodium lorentzianum), while other sparse information about spore size or surface ornamentation has been reported in various taxonomic studies (Pursell 1966; 1994; Crum

1 Programa de Pós-Graduação em Ecologia, Departamento de Botânica, Instituto de Ciências Biológicas, Universidade Federal de Juiz de Fora, 36036-900, Juiz de Fora, MG, Brazil

* Corresponding author: luizi.ponzo@uff.edu.br 
1972; Yano 1984; Yano \& Santos 1993; Stone 1997; Pursell \& Allen 2002; Daniels et al. 2012).

The sporoderm of mosses is known to include three strata: intine, exine and perine (Olesen \& Mogensen 1978; Neidhart 1979; Mogensen 1981; 1983). The perine may represent the only ornamented sporoderm stratum which has been considered a synapomorphy of mosses and tracheophytes (Mishler \& Churchill 1984; Bremer et al. 1987).

Spore morphology and ontogeny are important for evaluating bryophytes taxonomy and phylogeny, as evidenced by several studies (Clarke 1979; Horton 1982; Mishler \& Churchill 1984; Blackmore \& Barnes 1987; Brown \& Lemmon 1980; 1984a; b; 1988; 1991; Estébanez et al. 1997; Luizi-Ponzo et al. 1997; Caldeira et al. 2006; 2009; 2013; Luizi-Ponzo \& Melhem 2006a; b; Yano \& LuiziPonzo 2006; 2011; Savaroglu et al. 2007; Rocha et al. 2008; Savaroglu \& Erkara 2008; Alfayate et al. 2013; Brown et al. 2015; Rodrigues \& Luizi-Ponzo 2015; Savaroglu 2015; Savaroglu et al. 2017; Silva-e-Costa et al. 2017). Nonetheless, data are still scarce for Erpodiaceae (Erdtman 1965), or have been reported in taxonomic studies (Pursell 1966; 1994; Crum 1972; Yano 1984; Yano \& Santos 1993; Stone 1997; Pursell \& Allen 2002; Daniels et al. 2012).

The present study aimed to provide a detailed account of the morphology and ultrastructure of the spores of five species of Erpodiaceae from Brazil, in order to evaluate the taxonomic importance of spore morphology for the family and to facilitate their identification in past palynological records.

\section{Materials and methods}

\section{Studied specimens and palynological treatments}

The following species were selected for palynological study after an extensive review of herbaria material: Aulacopilum glaucum Wilson, Erpodium beccarii Müll. Hal., Erpodium coronatum (Hook. f. \& Wilson) Mitt., Erpodium glaziovii Hampe, and Erpodium pringlei E. Britton. The specimens used in the present study were obtained from the following herbaria: Herbarium Maria Eneyda P. K. Fidalgo of the Institute of Botany of São Paulo (SP), Herbarium of the Departament of Botany of the Museu Paraense Emílio Goeldi (MG) and Herbarium of the Botanical Garden of Rio de Janeiro (RB) (acronyms according to Thiers 2012).

\section{Examined material}

Aulacopilum glaucum Wils.: Brazil. Mato Grosso: Antônio João, 25/V/1976, D. Vital 6457 (SP*); Paraná: Clevelândia, 15/I/1983, O Yano et al. 5547 (RB); Paraná: Rio Negro, 28/I/1983, O. Yano \& J. R. Pirani 7134 (SP); Rio Grande do Sul: Condor, 19/I/1983, O. Yano et al. 5688 (SP); Rio
Grande do Sul: Panambi, 20/I/1983, O. Yano \& J. R. Pirani 5692 (SP); Santa Catarina: Chapecó, 21/IV/1983, O. Yano \& J. R. Pirani 6640 (SP); Santa Catarina: Xanxerê, 21/ IV/1983, O. Yano \& J. R. Pirani 6600 (SP); São Paulo: Bauru, 8/XII/1978, D. M. Vital 8391 (SP); São Paulo: Mirante do Paranapanema, 9/III/1981, O. Yano 3246 (SP). Erpodium beccarii Müll. Hal.: Brazil. Paraná: Maringá 2/X/1989, O. Yano 13433 (SP); Paraná: Medianeira 22/III/1982, O. Yano 4104 (SP*); São Paulo: Mirassol 17/VII/1892, O. Yano \& T. Yano 4442 (SP); São Paulo: Prataria, 8/VI/1985, O. Yano \& T. Yano 9494 (SP). Erpodium coronatum (Hook. \& Wils.) Mitt. Brazil. Mato Grosso: Guia 18/VI/1981, D. M. Vital 9950 (SP); Mato Grosso do Sul: Bonito 28/XI/1979, D. M. Vital 8588 (SP); Pernambuco: Inajá, 5/IX/1980, O. Yano \& Andrade Lima 2915 (SP); São Paulo: Dracena 25/ VIII/1983, O. Yano \& R. C. Compagnoli 8289 (SP); São Paulo: Fernandópolis 20/VII/1982, O. Yano \& T. Yano 4495 (SP*); São Paulo: Fernandópolis O. Yano \& T. Yano 4500 (SP); São Paulo: General Salgado 21/VII/1982, O. Yano \& T. Yano 4507 (SP). Erpodium glaziovii Hampe: Brazil. Espírito Santo: Aracruz 22/XI/1982, O. Yano et al. 4864 (SP); Espírito Santo: Colatina 23/XI/1982, O. Yano et al. 4890 (SP); Espírito Santo: Ibiraçu 22/ XI/1982, O. Yano et al. 4857 (SP*); Minas Gerais: Divino 24/XI/1982, O. Yano et al. 4975 (SP); Rio de Janeiro: Macaé 20/XI/1982, O. Yano et al. 4729 (SP); São Paulo: Guaratinguetá 18/XI/1982, O. Yano et al. 4711 (SP); O. Yano et al. 4713 (SP); São Paulo: Itu, 9/IX/1990, A. Schäfer-Verwimp 13152 (MG). Erpodium pringlei E. Britton: Brazil. Minas Gerais: Campanha 20/III/1983, O. Yano \& D. P. Santos 6300 (RB); Paraná: Jacarezinho 23/VIII/1983, O. Yano \& R. C. Compagnoli 8195 (SP*); Paraná: Maringá 16/III/1982, O. Yano 3961 (SP); Paraná: Terra Roxa 22/III/1982, O. Yano 4088 (SP); São Paulo: Águas de Lindóia, 8/IV/1990, O. Yano \& Z. R. de Melo 14459 (SP); São Paulo: Mirante do Paranapanema, 9/ III/1981, O. Yano 3248 (SP); São Paulo: São João da Boa Vista 22/III/1982, D. M. Vital 10357 (SP).

Qualitative and quantitative analysis of spores were performed under light microscopy (LM) before and after acetolysis following Wodehouse (1935) and Erdtman (1960), respectively. Both techniques were adapted to bryophytes according to Luizi-Ponzo \& Melhem (2006a). Palynological terminology follows Punt et al. (2007).

For scanning electron microscopy (SEM), spores were attached to specimen stubs that were previously covered with double-sided tape, and then sputter coated with a 20 nm layer of gold. For transmission electron microscopy (TEM), spores were fixed in $2.5 \%$ glutaraldehyde and rinsed four times in a buffer solution. Post-fixation was performed in $1 \%$ osmium tetroxide, followed three-hours later by dehydration in an alcohol series, embedding in Spurr resin, and heating at $70{ }^{\circ} \mathrm{C}$ for 48 hours. Ultrathin sections (65$70 \mathrm{~nm}$ ) were cut and then stained with uranyl acetate and lead citrate (Reynolds 1963). 


\section{Statistical analysis}

A minimum of four specimens was observed for each species. Mean values for spore diameter were calculated from measurements under LM of 100 spores for the reference specimen (RS; indicated by an * in Specimens Investigated List and the Tables), and 30 spores for comparison specimens (CS). Means (M), standard deviations $(S)$, standard errors $\left(S_{M}\right)$, ranges $\left(X_{\min }-X_{\max }\right)$, confidence intervals (CI), and variability $(\mathrm{V})$ are reported. Box-plot graphics were used to illustrate morphometric variation.

Measurements of each sporoderm stratum (perine, exine, and intine) from non-acetolyzed spores, and exine thickness from acetolyzed spores, were based on 10 spores per sample.

Measurements were submitted to the Shapiro-Wilk normality test and graphic evaluation, which revealed the data to be non-parametric (not normally distributed) ( $p$ value $\left.=1.338^{-12}\right)$. Thus, the non-parametric KruskallWallis test was used to test difference among and between data, followed by Dunnet's test (a posteriori analysis) to identify differences. Medians and data distribution were evaluated graphically. Statistical analysis and graphing were performed using R 3.5.1 (R Core Team 2018) and JMP', version 12 (SAS Institute, Cary, North Carolina, USA).

\section{Results}

Spores of the studied species of Erpodiaceae were found to be isomorphic (Fig. 1A-L), small to medium in size (13.20 to $39.60 \mu \mathrm{m}$, Fig. 2A), apolar, subcircular, inaperturate (Fig. 1A-F), and granulate (Fig. 1A, B, D, H, I, Tab. 1). There was no evidence of internal or external polarity of the spores (Fig. 1C, E, F).

Analysis by LM (Fig. 1B, F, G) and SEM (Fig. 1H, I) revealed that the elements of the perine consist of irregularly shaped and sized granules that occurr in isolation, overlapping or united, to form small walls (Fig. 1 A, C, D, H, I). Analysis by TEM revealed the perine to be more electron-dense than the exine, with its elements often exhibiting a very elaborate structure, such as a semitectum (Fig. 1J-L).

The exine was observed to be thin (Tab. 2), not uniformly shaped, and broken in some regions of the spore, under different preparations, but especially after acetolysis (Fig. 1A). TEM revealed the exine to be less electron-dense than the perine. The exine exhibits sharp and discrete projections, which sustain the elements of the perine (Fig. 1K-L).

The intine was observed to be thick (Tab. 2) and stratified, with a shiny interior region and a denser more-opaque external region (Fig. 1F, G, K, L). No particular pattern was observed in the thickness of the sporoderm, and it did not accompany any morphological changes in the other strata (Fig. 1B, E, F, G). TEM revealed the intine to have a fibrillar

Table 1. Morphometric data for spore diameter $(\mu \mathrm{m})$ of the five studied species of Erpodiaceae. ${ }^{*}$ reference specimen $(\mathrm{RS}) \mathrm{n}=100$; comparison specimens $(C S) \mathrm{n}=30$.

\begin{tabular}{|c|c|c|c|c|c|}
\hline Material & \multicolumn{2}{|c|}{$\left(X_{\min }-X_{\max }\right) M_{ \pm} S_{M}$} & s & $\mathrm{Cl}(95 \%)$ & $V(\%)$ \\
\hline \multicolumn{6}{|l|}{ Aulacopilum } \\
\hline A. glaucum Wilson D. M. Vital $6457^{*}(\mathrm{RS})$ & $(19.80-28.60)$ & $25.39 \pm \pm 0.23$ & 2.33 & $24.93-25.85$ & 9.18 \\
\hline O. Yano \& J. R. Pirani 6600(CS) & $(17.60-26.40)$ & $23.03 \pm \pm 0.38$ & 2.06 & $22.26-23.80$ & 8.94 \\
\hline O. Yano \& J. R. Pirani 7134(CS) & $(19.80-26.40)$ & $23.91 \pm \pm 0.38$ & 2.06 & $23.14-24.68$ & 8.62 \\
\hline O. Yano \& J. R. Pirani 6640(CS) & $(17.60-24.20)$ & $21.27 \pm \pm 0.35$ & 1.94 & $20.54-22.00$ & 9.12 \\
\hline O. Yano et al. 5547(CS) & $(15.40-19.80)$ & $17.60 \pm \pm 0.32$ & 1.73 & $16.95-18.25$ & 9.83 \\
\hline \multicolumn{6}{|l|}{ Erpodium } \\
\hline E. beccarii Müll. Hal. O. Yano $4104^{*}$ (RS) & $(24.20-37.40)$ & $30.62 \pm \pm 0.25$ & 2.48 & $30.13-31.11$ & 8.10 \\
\hline O. Yano \& T. Yano 4442(CS) & $(26.40-37.40)$ & $32.78 \pm \pm 0.52$ & 2.85 & $31.72-33.84$ & 8.69 \\
\hline O. Yano \& T. Yano 9494(CS) & $(24.20-35.20)$ & $29.85 \pm \pm 0.61$ & 3.35 & $28.60-31.10$ & 11.22 \\
\hline O. Yano $13433(\mathrm{CS})$ & $(19.80-28.60)$ & $23.39 \pm \pm 0.51$ & 2.80 & $22.35-24.43$ & 11.97 \\
\hline E. coronatum (Hook. f. \& Wilson) Mitt. O. Yano \& T. Yano 4495 *(RS) & $(28.60-39.60)$ & $33.84 \pm \pm 0.29$ & 2.88 & $33.27-34.41$ & 8.51 \\
\hline O. Yano \& T. Yano 4507(CS) & $(30.80-39.60)$ & $34.91 \pm \pm 0.48$ & 2.63 & 33.93-35.89 & 7.53 \\
\hline O. Yano \& R. C. Compagnoli 8289(CS) & $(26.40-37.40)$ & $31.02 \pm \pm 0.61$ & 3.34 & $29.77-32.27$ & 10.77 \\
\hline D. M. Vital 9950(CS) & $(28.60-39.60)$ & $35.42 \pm \pm 0.51$ & 2.79 & $34.38-36.46$ & 7.88 \\
\hline O. Yano \& T. Yano 4500(CS) & $(28.60-37.40)$ & $32.93 \pm \pm 0.49$ & 2.68 & $31.93-33.93$ & 8.14 \\
\hline E. glaziovii HampeO. Yano et al. $4857^{*}(\mathrm{RS})$ & $(15.40-26.40)$ & $19.51 \pm \pm 0.21$ & 2.11 & $19.09-19.93$ & 10.80 \\
\hline O. Yano et al. 4864(CS) & $(19.80-28.60)$ & $23.32 \pm \pm 0.44$ & 2.42 & $22.42-24.22$ & 10.38 \\
\hline O. Yano et al. 4711(CS) & $(13.20-28.60)$ & $23.32 \pm \pm 0.70$ & 3.81 & $21.90-24.74$ & 16.34 \\
\hline O. Yano et al. $4729(\mathrm{CS})$ & $(17.60-30.80)$ & $24.27 \pm \pm 0.66$ & 3.63 & $22.91-25.63$ & 14.96 \\
\hline A. Schäfer-Verwimp 13152(CS) & $(22.00-30.80)$ & $25.81 \pm \pm 0.47$ & 2.58 & $24.85-26.77$ & 10.00 \\
\hline E. pringlei E. Britton O. Yano \& R. C. Compagnoli 8195 *(RS) & $(19.80-28.60)$ & $25.85 \pm \pm 0.24$ & 2.43 & $25.37-26.33$ & 9.40 \\
\hline O. Yano \& D. P. Santos 6300(CS) & $(19.80-28.60)$ & $24.27 \pm \pm 0.43$ & 2.35 & $23.39-25.15$ & 9.68 \\
\hline O. Yano \& Z. R. de Melo 14459(CS) & $(22.00-30.80)$ & $25.37 \pm \pm 0.42$ & 2.29 & $24.51-26.23$ & 9.03 \\
\hline D. M. Vital 10357(CS) & $(17.60-28.60)$ & $23.98 \pm \pm 0.49$ & 2.67 & $22.98-24.98$ & 11.13 \\
\hline
\end{tabular}




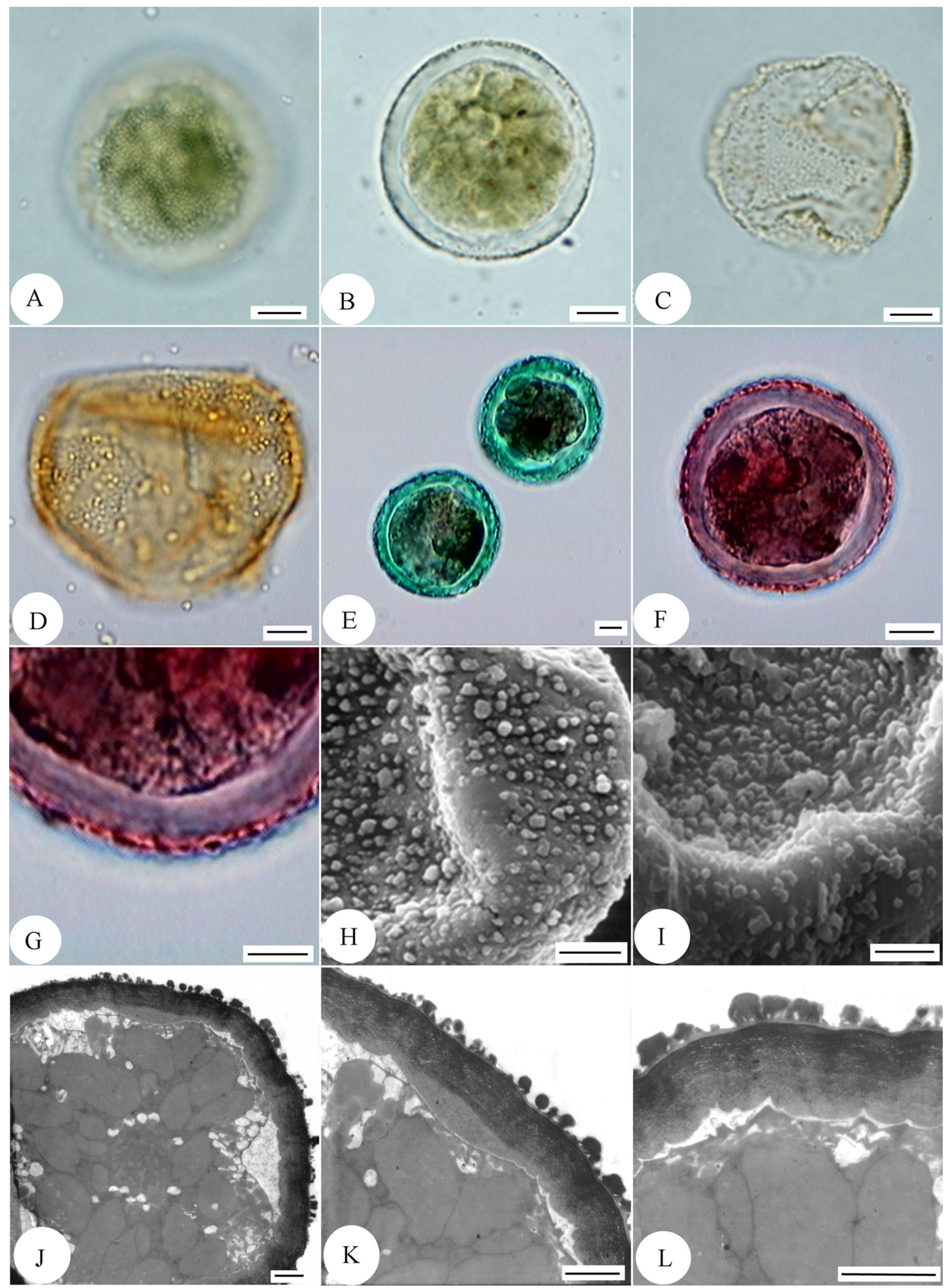

Figure 1. A-L. Spores of studied species of Erpodiaceae. A-C. Spores of Aulacopilum glaucum. A. Surface view of non-acetolyzed spore (LM). B. Sporoderm view of non-acetolyzed spore (LM). C. Surface view of acetolyzed spore (LM). D. Spores of Erpodium coronatum. Surface view of acetolyzed spore (LM). E-I. Erpodium beccarii E. General view of two non-acetolyzed spores (LM). F. Sporoderm view of non-acetolyzed spore (LM). G. Sporoderm detail of non-acetolyzed spore (LM). H. Sporoderm surface (SEM). I. Sporoderm detail (SEM). J-L. Erpodium pringlei. J. General view of non-acetolyzed spore (TEM). K. Detail of sporoderm of non-acetolyzed spore (TEM). L. Detail of sporoderm showing exine columns and stratified intine of non-acetolyzed spore (TEM). Scale bars: A-F: $5 \mu \mathrm{m}$ G-L: $2 \mu \mathrm{m}$. 

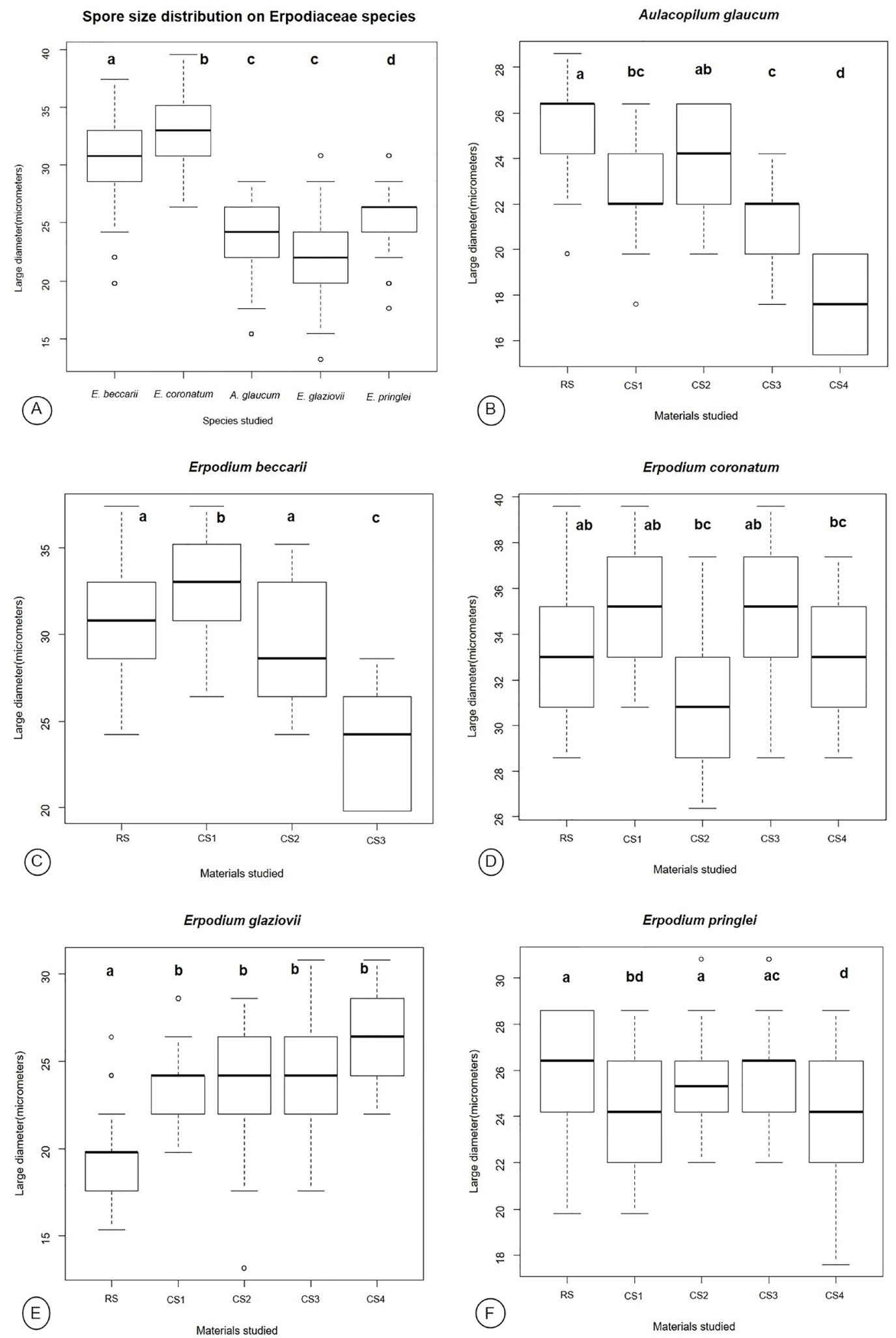

Figure 2. A-F. Boxplots representing spore size distribution for the five studied species of Erpodiaceae. A. Interspecific comparison of spore size. B. Intraspecific comparison of spore size for A. glaucum. C. Intraspecific comparison of spore size for E. beccarii. D. Intraspecific comparison of spore size for E. coronatum. E. Intraspecific comparison of spore size for E. glaziovii. F. Intraspecific comparison of spore size for E. pringlei. Error bars above and below the boxes indicate the 90th and 10th percentiles, while white circles represent outliers. Different letters (a, b, c, d) represent statistical differences among the specimens studied (i.e., specimens that do not have the same letters are statistically different; Kruskall-Wallis test and Dunnet's test, $\mathrm{p}<0.05$ ). 
appearance, to be more compact in the area adjacent to the exine, and to possess stratification (Fig. 1J-L).

Observations demonstrated spore mortality to be low, and this indicates the absence of any phenomenon related to aborted spores. Kruskall-Wallis and Dunnet's tests revealed a statistically significant difference among species for the specimens analyzed ( $\mathrm{p}<0.0001$ for both tests) (Fig. 2A). Statistically significant intra-specific variation was also detected for all species studied ( $\mathrm{p}<0.0001$ for A. glaucum, E. beccarii, E. coronatum, and E. glaziovii; $\mathrm{p}=0.0003$ for E. pringlei:) (Fig. 2B-F). Inter- and intraspecific variation precluded distinguishing the studied species based on spore size.

Table 2. Mean thickness ( $\mu \mathrm{m}$ ) of sporoderm strata for spores of of the five studied species of Erpodiaceae, before and after" acetolysis.

\begin{tabular}{|c|c|c|c|c|}
\hline \multirow{2}{*}{ Species } & \multicolumn{4}{|c|}{ Sporoderm strata } \\
\cline { 2 - 5 } & exine $^{*}$ & exine & intine & perine \\
\hline $\begin{array}{c}\text { Aulacopilum glaucum Wilson D. M. } \\
\text { Vital 6457 *(RS) }\end{array}$ & 0.46 & 0.48 & 2.32 & 0.54 \\
\hline $\begin{array}{c}\text { Erpodium beccarii Müll. Hal. O. Yano } \\
\text { 4104 *(RS) }\end{array}$ & 0.47 & 0.52 & 2.50 & 0.64 \\
\hline $\begin{array}{c}\text { E. coronatum (Hook. f. \& Wilson) } \\
\text { Mitt. O. Yano \& T. Yano 4495 *(RS) }\end{array}$ & 0.45 & 0.46 & 2.84 & 0.66 \\
\hline $\begin{array}{c}\text { E. glaziovii Hampe O. Yano et al. } \\
\text { 4857 (RS) }\end{array}$ & 0.49 & 0.52 & 2.44 & 0.58 \\
\hline $\begin{array}{c}\text { E. pringlei E. Britton O. Yano \& R. C. } \\
\text { Compagnoli 8195 *(RS) }\end{array}$ & 0.42 & 0.44 & 2.60 & 0.70 \\
\hline
\end{tabular}

\section{Discussion}

Previous descriptions of the spores of some species of Erpodiaceae (Pursell 1966; 1994; Yano \& Santos 1993; Daniels et al. 2012) revealed differences in size and slight variation in surface ornamentation. The surface ornamentation was characterized as "papillose", except for Erpodium coronatum for which the spores were considered essentially smooth (Pursell 1966; 1994; Yano \& Santos 1993). The present study found the spores of this species to have the most delicate ornamentation among those studied.

Crum (1972) referred to spores of Erpodiaceae as "relatively large (18-44 $\mu \mathrm{m})$, and scabrate, nearly smooth". This variation in size corresponds to the small and medium size classes of Erdtman (1952), which is in agreement with the present study.

When describing spores of Erpodium beccarii (as Erpodium lorentzianum), Erdtman (1965) reported an inaperturate condition and a surface with circular or irregularly shaped processes. These features are similar to those found for the species of the present study. However, it is worth noting that, according to Erdtman (1965), the exine is the stratum responsible for spore ornamentation, while the present study found the perine to be responsible, which is consistent with the observations of McClymont \& Larson (1964),
Olesen \& Mogensen (1978), Neidhart (1979) and Brown \& Lemmon (1980; 1984a; 1988), and more recent papers on moss spores (Caldeira et al. 2013; Rodrigues \& Luizi-Ponzo 2015; Savaroglu 2015; Savaroglu et al. 2017).

The perine totally or partially covers the exine and is thus largely responsible for spore surface ornamentation. The electron density of the perine, and its resistance to acetolysis, indicated it to be composed of lipidic and sporopollenin material, as also reported for moss species by Neidhart (1979).

Observations under TEM revealed the presence of projections from the exine that occur in isolation or sustain the elements of the perine. Sporoderm structure with features similar to the semitectum of pollen grains has not been previously reported for spores of mosses in the literature consulted and thus represents an important morphological character evidencing the close relationship of these plants to tracheophytes, as previously pointed out by some authors, but especially Mishler \& Churchill (1984), who included perine ontogeny in their phylogenetic analysis.

Intine thicknesses was found to be not associated with exine thickness in the species of the present study. This observation, associated with the irregular rupture of the exine while submitted to acetolysis, confirms the absence of an apertural area and the inaperturate, and apolar condition of these spores. Although an aperture at the proximal pole is common in mosses, the absence of an apertural region has been reported for spores of the haplolepidous moss Fissidens crispus (as Fissidens limbatus) by Mueller (1974) and for some spores of Grimmiaceae by Estébanez et al. (1997). It is interesting to note that the apolar condition reported here for spores of Erpodiaceae demonstrates the absence of internal polarity, as also observed by Mueller (1974) for species of Fissidens. On the other hand, Estébanez et al. (1997) found evidence of spore polarity for species of Grimmiaceae.

The intine stratification found for the studied species indicates a relationship with the arrangement of the fibrils, which are more compact in the area adjacent to the exine. Such stratified condition of the intine has also been reported for haplolepidous mosses, such as Fissidentaceae (Mueller 1974), and Grimmiaceae (Estébanez et al. 1997), as well as for taxa considered more distant, such as the cleistocarpous family Archidiaceae, in which the stratified intine possesses a great number of layers (McClymont \& Larson 1964; Miles \& Longton 1992). Luizi-Ponzo \& Melhem (2006a) reported stratified intine for spores of Helicophyllaceae, evidencing heterogeneity in the distribution of this feature among mosses.

The palynological observations reported here do not permit separating neither the genera nor the species of Erpodiaceae, but can be considered to reflect a common evolutionary pattern for the family, especially with regard to the configuration of the perine and intine. These results 
represent information that can be of important relevance to future phylogenetic analyses, as there was no consensus among the authors on previous studies (De Luna 1995; Goffinet et al. 1998). The spores of the studied species were resistant to acetolysis, and so their occurrence in historical records can be expected.

\section{Acknowledgements}

The authors thank Therezinha Melhem, Olga Yano, Maria Amelia Barros, Vania Esteves, Nicholas McLetchie for support, and all those who collaborated in this work, and the herbaria curators for the loaned material. This research received grants from Fundação de Amparo à Pesquisa do Estado de Minas Gerais (FAPEMIG) and from the Coordenação de Aperfeiçoamento de Pessoal de Nível Superior (CAPES) - Finance Code 001; and was partially conducted during the validity of a scholarship to JCSC, supported by CAPES.

\section{References}

Alfayate C, Ron E, Estébanez B, Pérez-Batista MA. 2013 Mature spores of four pleurocarpous mosses in the Canary Islands: ultrastructure and early germination stages. The Bryologist 116: 97-112.

Blackmore S, Barnes SH. 1987. Embryophyte spore walls: origin, development, and homologies. Cladistics 3: 185-195.

Bremer K, Humphries CJ, Mishler BD, Churchill SP. 1987. On cladistic relationships in green plants. Taxon 36: 339-349.

Brown RC, Lemmon BE. 1980. Ultrastructure of sporogenesis in a moss: Ditrichum pallidum. III. Spore wall formation. American Journal of Botany 67: 918-934.

Brown RC, Lemmon BE. 1984a. Ultrastructure of sporogenesis in the moss Amblystegium riparium. II. Spore wall development. Journal of the Hattori Botanical Laboratory 57: 139-152.

Brown RC, Lemmon BE. 1984b. Spore wall development in Andreaea (Musci: Bryopsida). American Journal of Botany 71: 412-420.

Brown RC, Lemmon BE. 1988. Sporogenesis in Bryophytes. Advances in Bryology 3: 159-223.

Brown RC, Lemmon BE. 1991. Sporogenesis in simple land plants. In: Blackmore S, Barnes SH. (eds.) Pollen and spores. Patterns of diversification. Oxford, Clarendon Press. p. 9-24.

Brown RC, Lemmon BE, Shimamura M, Villarreal JC, Renzaglia KS. 2015. Spores of relictual bryophytes: Diverse adaptations to life on land. Review of Palaeobotany and Palynology 216: 1-17.

Caldeira IC, Gonçalves-Esteves V, Luizi-Ponzo AP. 2006. Morfologia dos esporos das espécies de Leucobryaceae Schimp. (Bryophyta) do Parque Estadual de Ilha Grande, Município de Angra dos Reis, Estado do Rio de Janeiro. Revista Brasileira de Botânica 29: 301-307.

Caldeira IC, Gonçalves-Esteves V, Luizi-Ponzo AP. 2009 Morfologia dos esporos de Sematophyllaceae Broth. ocorrentes em três fragmentos de Mata Atlântica, no Rio de Janeiro, Brasil. Revista Brasileira de Botânica 32: 299-306.

Caldeira IC, Gonçalves-Esteves V, Luizi-Ponzo AP. 2013. Palynology of selected species of Fissidens (Hedw.). Plant Systematics and Evolution 299: 187-195.

Clarke GCS. 1979. Spore morphology and bryophyte systematics. In: Clarke CGS, Duckett JG. (eds.) Bryophyte systematics. London, Academic Press. p. 231-250.

Costa DP, Pôrto KC, Luizi-Ponzo AP, et al. 2011. Synopsis of the Brazilian moss flora: checklist, distribution and conservation. Nova Hedwigia 93: 277-334
Crum HA. 1972. A taxonomic account of the Erpodiaceae. Nova Hedwigia 23: 201-224.

Daniels AED, Mabel JL, Daniel P. 2012. The Erpodiaceae (Bryophyta: Isobryales) of India. Taiwania 57: 168-182.

De Luna E. 1995. The circumscription and phylogenetic relationships of the Hedwigiaceae (Musci). Systematic Botany 20: 347-373.

Erdtman G. 1952. Pollen morphology and plant taxonomy. Angiosperms. An introduction to palynology I. Stockholm, Almqvist and Wiksell.

Erdtman G. 1960. The acetolysis method. A revised description. Svensk Bot Tidskr 39: 561-564.

Erdtman G. 1965. Pollen and spore morphology/ plant taxonomy. Gymnospermae, Bryophyta (Text). An introduction to palynology III. Stockholm, Almqvist and Wiksell.

Estébanez B, Alfayate C, Ron E. 1997. Observations on spore ultrastructure in six species of Grimmia (Bryopsida). Grana 36: 347-357.

Faria ALA, Mundim JV, Moura OS, Soares AER. 2018. Erpodiaceae. In: Flora do Brasil 2020 em construção. Jardim Botânico do Rio de Janeiro. http://floradobrasil.jbrj.gov.br/reflora/floradobrasil/FB96274. 17 Sep. 2018.

Frey W, Stech M. 2009. Marchantiophyta, Bryophyta, Anthocerotophyta. In: Frey W. (ed.) Syllabus of plant families. Part 3. Berlin, Stuttgart, Gebr. Borntraeger. p. 9-263.

Goffinet B, Bayer RJ, Vitt DH. 1998. Circumscription and phylogeny of the Orthotrichales (Bryopsida) inferred from rbcL sequence analyses. American Journal of Botany 85: 1324-1337.

Goffinet B, Buck WR, Shaw JA. 2009. Morphology, anatomy, and classification of the Bryophyta. In: Goffinet B, Shaw JA. (eds.) Bryophyte biology. 2nd. edn. New York, Cambridge University Press. p. 55-138.

Horton DG. 1982. The evolutionary significance of superficial spore characters in the Bryidae. Journal of the Hattori Botanical Laboratory 53:99-105.

Luizi-Ponzo AP, Melhem TS. 2006a. Spore morphology and ultrastructure of the tropical moss Helicophyllum torquatum (Hook.) Brid. (Helicophyllaceae) in relation to systematics and evolution. Cryptogamie. Bryologie 27: 413-420.

Luizi-Ponzo AP, Melhem TS. 2006b. Palinotaxonomia de Rhachitheciaceae (Bryophyta) do Brasil. Boletim do Instituto de Botânica de São Paulo 18: 91-99.

Luizi-Ponzo AP, Barth OM, Lisboa RCL. 1997. Estudos palinológicos em briófitas. In: Lisboa PLB. (ed.) Caxiuanã. Belém, Museu Paranaense Emílio Goeldi \& MCT/CNPQ. p. 305-318.

McClymont JW, Larson DA. 1964. An electron-microscope study of spore wall structure in the Musci. American Journal of Botany 51: 195-200.

Miles CJ, Longton RE. 1992. Spore structure and reprodutive biology in Archidium alternifolium (Dicks. ex Hedw.) Schimp. Journal of Bryology 17: 203-222.

Mishler BD, Churchill SP. 1984. A cladistic approach to the phylogeny of the "bryophytes". Brittonia 36: 406-424.

Mogensen GS. 1981. The biological significance of morphological characters in Bryophytes: The spore. The Bryologist 84: 187-207.

Mogensen GS. 1983. The spore. In: Schuster RM. (ed.) New manual of bryology. Nichinan, The Hattori Botanical Laboratory. p. 326-341.

Mueller DMJ. 1974. Spore wall formation and chloroplast development during sporogenesis in the moss Fissidens limbatus. American Journal of Botany 61: 525-534.

Neidhart HB. 1979. Comparative studies of sporogenesis in bryophytes. In: Clarke CGS, Duckett JG. (eds.) Bryophyte Systematics. London, Academic Press. p. 251-280.

Olesen P, Mogensen GS. 1978. Ultrastructure, histochemistry and notes on germination stages of spores in selected mosses. The Bryologist 81: 493-516.

Punt W, Hoen P, Blackmore S, Nilsson S, Le Thomas A. 2007. Glossary of pollen and spore terminology. Review of Palaeobotany and Palynology 143: 1-81.

Pursell RA. 1966. Notes on American Erpodiaceae, with descriptions of two new species. The Bryologist 69: 461-471.

Pursell RA. 1994. Erpodiaceae. In: Sharp AJ, Crum H, Eckel ME. (eds.) The moss flora of Mexico. Monographs in Systematic Botany from 
the Missouri Botanical Garden. Vol. 69. St. Louis, Missouri Botanical Garden Press. p. 581-588.

Pursell RA, Allen BH. 2002. Erpodiaceeae. In: Allen BH. (ed.) Moss flora of Central America. Monographs in Systematic Botany from the Missouri Botanical Garden. Vol. 90. St. Louis, Missouri Botanical Garden Press. p. 523-531

R Core Team. 2018. R: A language and environment for statistical computing. Vienna, R Foundation for Statistical Computing. https://www.R-project. org/.

Reynolds ES. 1963. The use of lead citrate at high pH as an electronopaque stain in electron microscopy. The Journal of Cell Biology 17: $208-212$

Rocha LM, Gonçalves-Esteves V, Luizi-Ponzo AP. 2008. Morfologia de esporos de espécies de Polytrichaceae Schwägr. (Bryophyta) do Brasil. Revista Brasileira de Botânica 31: 537-548.

Rodrigues RS, Luizi-Ponzo AP. 2015. Palinologia de espécies selecionadas da família Pottiaceae (Bryophyta). Pesquisas, Botânica 67: 303-317.

Savaroglu F. 2015. Spore morphology of some Orthotrichaceae Arn. species (Bryophyta) from Turkey. Bangladesh Journal of Botany 44: 499-506.

Savaroglu F, Erkara JP. 2008. Observations of spore morphology of some Pottiaceae Schimp. Plant Systematics and Evolution 271: 93-99.

Savaroglu F, Erkara JP, Bayçu C, Alkan M. 2007. Spore morphology of some Bryaceae Schwägr. species (Bryophyta) from Turkey. International Journal of Natural and Engineering Sciences 1: 49-54.

Savaroglu F, Erkara JP, Koyuncu O. 2017. Observations of spore morphology of some species of Hypnaceae Schimp. (Bryophyta) in Turkey. Bangladesh Journal of Botany 46: 9-17.
Silva-e-Costa JC, Luizi-Ponzo AP, Resende CF, Peixoto PHP. 2017. Spore germination, early development and some notes on the effects of in vitro culture medium on Frullania ericoides (Nees) Mont. (Frullaniaceae, Marchantiophyta). Acta Botanica Brasilica 31: 19-28.

Stone IG. 1997. A revision of Erpodiaceae with particular reference to Australian taxa. Journal of Bryology 19: 485-502.

Thiers B. 2012. Index Herbariorum: A global directory of public herbaria and associated staff. New York Botanical Garden's Virtual Herbarium. http://sweetgum.nybg.org/ih

Vital DM. 1980. Erpodiaceae (Musci) do Brasil. MSc Thesis, Universidade Estadual de Campinas, Campinas.

Wodehouse RP. 1935. Pollen grains: Their structure, identification and significance in science and medicine. New York, McGraw-Hill.

Yano O. 1984. Ocorrência de Aulacopilum glaucum Wils. (Erpodiaceae, Bryopsida) no Brasil. Anais do IV Congresso Sociedade Botânica de São Paulo 4: 77-82.

Yano O. 2011. Catálogo de musgos brasileiros: literatura original, basiônimo, localidade-tipo e distribuição geográfica. Folhetos e Manuais, e Publicações on-line do Instituto de Botânica. http://botanica.sp.gov. br/files/2013/09/virtuais_2musgos.pdf

Yano O, Luizi-Ponzo AP. 2006. Chonecolea doellingeri (Chonecoleaceae, Hepaticae), taxonomia e distribuição geográfica no Brasil. Acta Botanica Brasilica 20: 783-788.

Yano O, Luizi-Ponzo AP. 2011. Dumortiera hirsuta (Dumortieraceae, Marchantiophyta), taxonomy, palynology and geographic distribution. Boletim do Instituto de Botânica 21: 9-18.

Yano O, Santos MSX. 1993. Musgos da Gruta de Mirassol (São Paulo). Acta Botanica Brasilica 7: 89-106. 